\title{
TRACE SHAPE AND MULTI-ATTRIBUTE SEISMIC FACIES ANALYSIS APPLIED TO PALEOCENE/ EOCENE RESERVOIRS ON DEEPWATER CAMPOS BASIN
}

\author{
Carlos Eduardo Abreu' \\ Bruno de Ribet $^{2}$ \\ Recebido em 27 de fev., 2002 / Aceito em 7 de nov., 2003 \\ Received Feb. 27, 2002 / Accepted Nov. 7, 2003
}

\section{ABSTRACT}

This paper illustrates a new reservoir characterization approach using seismic pattern recognition methodology based on princip al component analysis, trace shape and 3D multi-attributes classification on a set of 3D seismic data volumes. We develop the reservoir interpretation workflow (figure 1) as follows:

1) Seismic facies maps obtained by Kohonen's Self Organizing Map (SOM) Neural Network method to seismic facies volume from a set of various seismic attributes, obtained by Hierarchical classification method; and

2) Statistical analysis of available seismic attributes by application of Principal Component Analysis (PCA) statistical method before classification.

How to discriminate the amount of information that each geophysicist is dealing with, in a reservoir characterization process and what is the suitable procedure to help to discriminate between data and information?

We present some results of its application on the Paleocene/Eocene reservoirs of a Campos Basin field.

Keywords: seismic attributes, seismic facies, reservoir characterization

\section{RESUMO}

Este trabalho ilustra uma nova abordagem para caracterização de reservatórios usando metodologia de reconhecimento de padrão sísmico baseado em análise do componente principal, forma do sinal e classificação de multi-atributos 3D em um volume de dados sísmicos 3D. Nós desenvolvemos o fluxograma de interpretação do reservatório como se segue:

1) Mapas de fácies sísmicas obtidos pelo método de Rede Neural Mapa Auto-Organizável de Kohonen (SOM) para volume de fácies sísmicas, a partir de um conjunto de vários atributos sísmicos obtidos pelo método de classificação Hierárquica; e

2) Análise estatística dos atributos sísmicos disponíveis pela aplicação do método estatíistico de Análise de Componente Principal (PCA) antes da classificação. Como discriminar a quantidade de informações em que cada geofísico está envolvido, em um processo de caracterização de reservatório e qual o procedimento indicado para ajudar a discriminação entre dado e informação?

Apresentamos alguns resultados desta aplicação nos reservatórios do Paleoceno/Eoceno de um campo na Bacia de Campos.

Palavras-chave atributos sísmicos, fácies sísmicas, caracterização de reservatórios.

\footnotetext{
' PETROBRAS, Brazil.

2 Paradigm Latin America, Argentina
} 


\section{INTRODUCTION}

The project has been carried out on a Campos Basin offshore oil field. Seismic attribute analysis discriminates oil-saturated Paleocene, Eocene and Oligocene sandstones encased in shale and marls mainly in stratigraphic traps. The reservoirs are turbidite sandstones, deposited in bathyal settings controlled by halokinetic-generated depocenters and grabens.

There are four stacked reservoirs of Late Paleocene, Middle Eocene (2 zones) and Late Oligocene age, the main oil zones are the Oligocene reservoir with $56 \%$ and the lowermost Middle Eocene with 36\% of the original oil-in-place volume.

Our interval of interest is the sequence Late Paleocene/Middle Eocene. It covers the Corvina C0100, Enchova EN110 and EN120, Barracuda BR1 10 and BR 120 reservoirs. The deposition, at the level of the selected reservoirs, has been clearly controlled by the fault system, within the 2 major grabens of the field, except the C0100 present over the whole area.

Eight seismic attributes were available in the project and the information carried out by those attributes could be mostly represented by a lower number of original attributes or by a set of new attributes defined as a combination of the original attributes (PCA attributes).
The results have been compared to the actual understanding of the field, based, for example on the NTG maps and production data from wells.

Whatever the type of input data (Traces or volumes), the seismic facies classification process helped enhance the geological model of the reservoir, and delivered a $3 \mathrm{D}$ facies model.

\section{METHODOLOGY}

The technology and methodology, presented in this paper, are based on unsupervised (competitive learning algorithm) trace shape classification, Principal Component Analysis and 3D seismic multiattribute volume classification.

The objective of a classification process is to describe enough variability of the seismic to reveal details of the underlying geological features while preserving a global synthesis for the seismic signal changes. Artificial Neural Networks, Principal Component Analysis and Cluster Analysis techniques have been used to achieve this data reduction and classification. The project has been carried out by using multi-attribute seismic facies classification techniques, based on the Seisfacies ${ }^{\mathrm{TM}}$ program (trademark of Paradigm), which gathers these seismic facies analysis technologies (Figure 1).

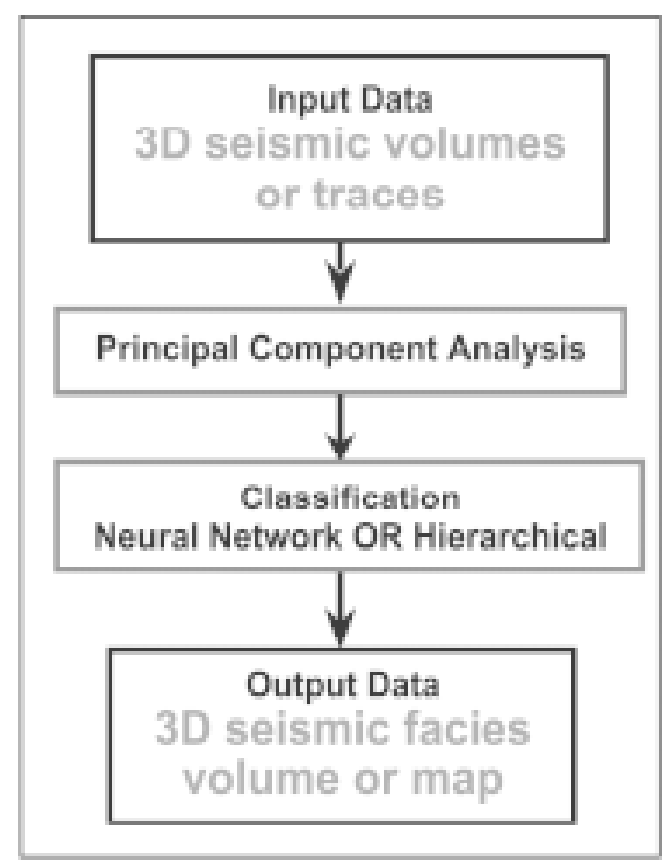

Figura 1 - Fluxograma genérico para classificação das fácies sísmicas. PCA e o método estatístico aplicado para redução da quantidade de dados disponíveis, especialmente aplicado em atributos de volumes sísmicos 3D.

Figure I - Seismic facies classification generic workflow: PCA is the statistical method applied for downsizing the amount of available data, especially applied on 3D seismic volume attributes. 
The Principal Component Analysis is a widely known statistical method, defined as a description tool of a dataset, which presents numerous quantitative characteristics, as are the seismic attributes. It searches for a latent structure, which means beyond the single described variables. It is applied in our case to analyze data redundancy and to bring several individual attributes volumes to a fewer PCA volumes for further analysis. This method will help to understand which attributes are contributing the most in describing the variance and trend of the dataset, the attributes dependencies and correlation and to eliminate noise, embedded in the original data. By applying this methodology on the N samples within an interval for a selected seismic attribute, the resulting principal components are sorting a different level of useful information to reveal possible undetected geological features, like channels, small discontinuities, etc...

Seismic trace shapes within an interval are defined by the values of the $\mathrm{N}$ seismic samples along the traces. To analyze and classify the traces, it is natural to look into a N-dimensional cross-plot defined by the $N$ seismic samples, defined as the input space. In this cross-plot, each trace is represented by one point which co-ordinates are defined by the $\mathrm{N}$ values of its samples. Points that are close in the cross plot mean similar seismic shape. Points that are apart from each other imply different seismic shapes and possible different geological environment. Classification is looking at the organization of the points within the Ndimensional cloud.

The volume classification technique requires multiple 3-D seismic attribute volumes as input. The output is a single 3-D seismic classification volume, where a class number and a color being assigned to each seismic sample. The assumption is that two samples belongs to the same class, consequently to the same "seismic facies", if they are characterized by similar values of all input seismic attribute volumes. Therefore, they likely correspond to a similar geological environment, defined from the selected seismic attributes. The purpose of this 3D multi-attributes classification is, within a unique process, the simultaneous integration of the information from multiple seismic attributes to produce a single $3 D$ seismic facies volume that can be investigated like any other attribute.

\section{TEMPORAL AND SPATIAL RESTRICTIONS}

In our approach, those techniques use an interval approach. Seismic samples selected for the analysis come from a user-defined interval. Boundaries of the interval can be parallel to one seismic event (constant time interval) or limited by two events (seismic interval with variable temporal thickness), defining a consistent stratigraphic unit. When the seismic facies are analyzed in a time window at the reservoir level defined for analyzing the shape of the trace, the reliability and accuracy of this interpretation are crucial points, especially for short time windows over a detailed area. An adjusted reference horizon will not introduce bias and has a neutral impact on the definition of the synthetic neurons that summarize the variability of the seismic trace shape within the interval of interest.

On the opposite, as the 3D multi-attribute seismic facies classification is based on a sample-to-sample approach, it is less sensitive to the interval definition than the seismic trace shape analysis, as we are looking for homogeneous clusters.

By restricting the spatial zone of interest, the amount of input information is less and therefore easier to discriminate. The objective of defining an area is to constrain the application of the methodology to a consistent geological or structural feature. This results in an increase of details, where the control of the different patterns observed in the zone of interest is higher, if the number of clusters is equal to the used number with the process without restriction.

\section{TRACE CLASSIFICATION}

Whatever the input seismic attribute or combination of attributes, in an unsupervised mode, this algorithm seeks by itself, some structure or organization in the input data set. Kohonen's Self Organizing Map (SOM) Neural Network (NNT) method is one of the most suitable algorithms in the Arrificicial Intelligence area, for classifying the seismic information (JOHANN; RIBET, 1999). The results will reflect the variation of the characteristics of the original input dataset, without considering its proper values.

The SOM Neural Network (TotalFinaElf patented) is the main engine for trace shape classification. The classification consists of 2 steps. The $1^{\text {st }}$ is to create, from a learning data set extracted from the raw data, a suite of synthetic traces or neurons, which represents the variability of the attribute in the interval of interest. Each neuron is associated to a specific color (Figure 2). The $2^{\text {nd }}$ step consists to search for the best correlation between the real seismic traces and each trace of the model. For the best correlation, the real seismic trace is associated to the corresponding neuron color. The result is a map of seismic facies where identical color should indicate a similar shape and seismic response to the geological environment, depending of the input attribute. From 3D information set, the result of the shape variation will be presented as a map, which has the ability to simplify the understanding of the geological features, present in the interval.

In Seisfacies ${ }^{\mathrm{TM}}$ the Self Organizing Map method generates topologically related clusters, which is underlined by a gradual change in the color palette and the ordered suite of neurons, in relation with the changes in the shape of the trace. The algorithm is not affected by 

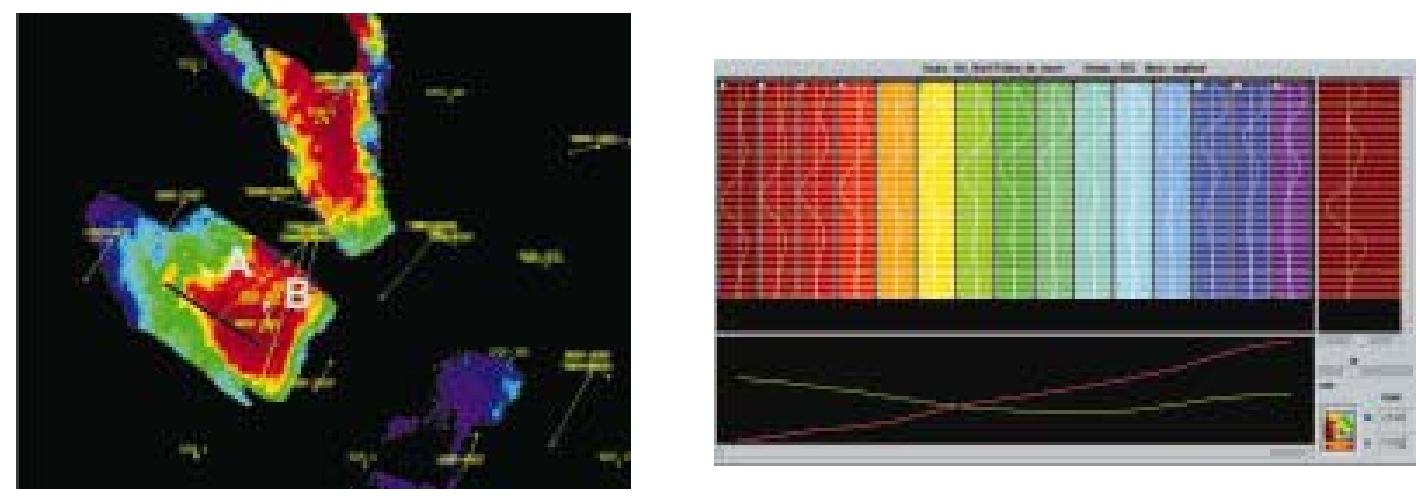

Figura 2 - Mapa de fácies sísmicas extraído do intervalo entre o topo dos horizontes do Paleoceno e do Maastrichtiano. 0 painel da direita e o modelo sintético deduzido dos dados sísmicos através de NNT. A curva verde indica a correlação entre o traço real selecionado (Inline 2740, CDP 1795) e cada neurônio do modelo. A maior correlação ocorre entre o neurônio 1 e a cor marrom é afetada por este traço sísmico.

Figure 2 - Seismic facies map extracted from top of Paleocene and Maastrichtian horizons interval. The right panel is the synthetic model deduced from the seismic data trough NNT. The green curve indicates the correlation between the selected real trace (Inline 2740, CDP 1795) and each neuron of the model. The highest correlation is with the neuron 1 and the brown color is affected to this seismic trace.

attribute amplitude variations, noise and the resulting seismic facies map leads to gradual changes in seismic shape, as mostly being observed from a real geological environment.

One or a combination of seismic attributes may define a dataset. In the case of several seismic attributes, the resulting neuron will be a composite trace of all neurons, each one per type of data.

The application on an interval defined by the tops of the Paleocene and Maastrichtian horizons displays clearly the spatial distribution of the brown facies into the southern graben, which mostly indicates a possible deposition from the northern graben and not from the NW of the southern graben, as previously established (Figure 2). As the definition of our interval is consistent with the geology, this result could indicate that the structural framework of the grabens was different at the time of deposition. In the southern graben, it displays the change of facies (figure 2) observed between the 2 main wells, which are situated in a different facies and therefore in a different geological environment. This result has been confirmed by pressure tests, which indicate depletion at the location of the well $A$.

\section{SEISMIC MULTI-ATTRIBUTES ANALYSIS}

Reservoir characterization is increasingly dependent upon high quality seismic data and the attributes that may derive from it. The purpose of our project is based on the use of a known set of seismic attributes, to establish which one or combination could bring the more appropriate and objective discrimination for describing rocks and fluid properties in the reservoir.

The previous stage to any further project will be to concentrate on the available attributes, in order to check their quality and to incorporate new classes of attributes derived from post stack or pre stack seismic data.

In our project, 8 seismic attributes were available: Full stack, Near, Far, Acoustic impedance (P), Shear Wave impedance, Coherence from full stack, Poisson's ratio and combination of $P$ and Shear Wave impedances (Figure 3).

To improve the results of the multi-attribute classification, an analysis step was carried out with the Principal Component Analysis method. It is a mathematical procedure that finds principal directions in a multi-dimensional data set and determines the optimal shift and rotation of the data, so that it is expressed in those principal directions. Seismic samples from input volumes are projected into a multidimensional cross-plot, where the number of dimensions corresponds to the number of input volumes. Then, the main data trends (principal axes) are found in the data cloud. The data samples are projected on the principal axes. The output of this procedure is a set of new 3-D volumes named PCA components, of which the number of components is equal to 


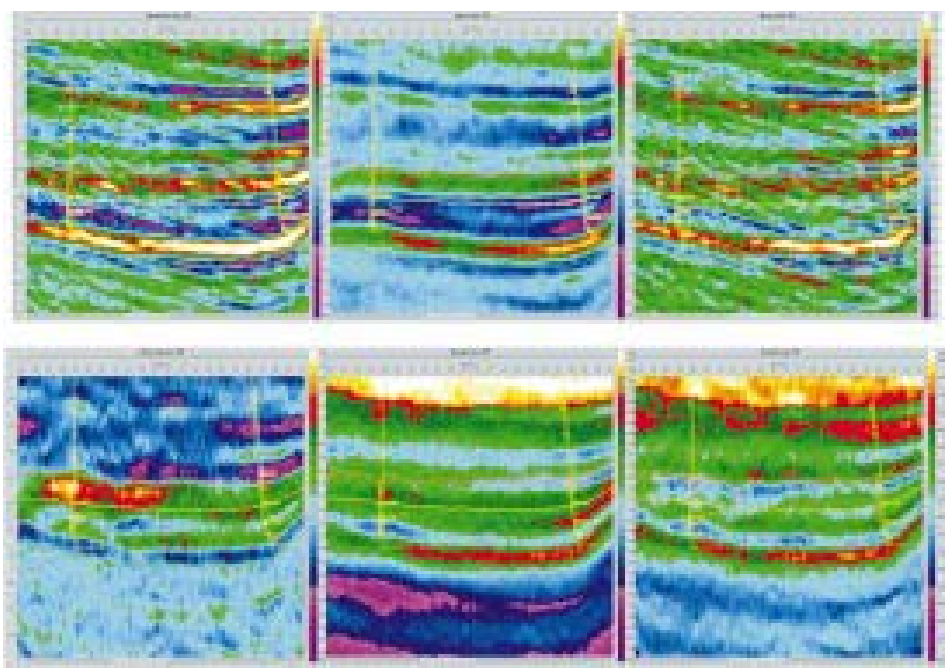

Figura 3 - Atributos sísmicos disponíveis. Do canto esquerdo superior para o canto direito inferior: Amplitude do empilhamento total, AV0 traços afastados e próximos, combinação das impedâncias das ondas $\mathrm{P} e \mathrm{~S}$, impedância da onda $\mathrm{P}$, impedância da onda $\mathrm{S}$.

Figure 3 - Available seismic attributes. From top left to bottom right: Full stack amplitude, AVO far and near, combination of $P$ and Shear Wave impedances, $P$ impedance, Shear wave impedance.

the number of input data. The PCA components are ranked in accordance with the amount of their contribution to the data, based on Eigen values, contribution and cumulated inertia (Table 1). The least important PCA components contain noise and are usually removed from the following classification process (Figure 4). PCA is a useful analytical tool to determine the correlation between the input space attributes (Table 1) and therefore to select the most important attribute components to be used in the non-linear discrimination (Table 2).

Tabela 1 - Matriz de correlação e contribuição de cada componente principal representando a informação original. Table I - Correlation matrix and contribution of each principal component to represent the original information.

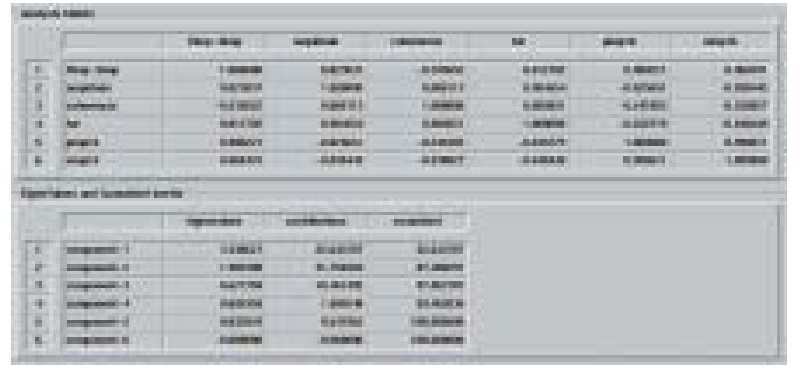

Tabela 2 - Contribuição de cada atributo sísmico original na definição dos seis componentes principais. Table 2 - Contribution of each original seismic attribute in the definition of the 6 principal components.

\begin{tabular}{|c|c|c|c|c|c|c|c|}
\hline & & & & & & - & \\
\hline 1 & $r=1$ & caras & .50mi & COLE & aesne & 2060 & .00 \\
\hline$z$ & vepoed it & tanes: & cones & ones & cavam & then & inex \\
\hline , & 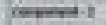 & einen & $+\operatorname{com} r$ & tersion & *niven & tirm & innes \\
\hline 4 & mese & twaie & - expar & tumes & crave & $=-m$ & cotan \\
\hline 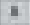 & $=4$ & 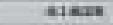 & sear & $=0$ & Anewi & ane & sama \\
\hline " & 10ponst & t. & 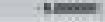 & 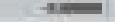 & tas & $=$ & sim \\
\hline
\end{tabular}




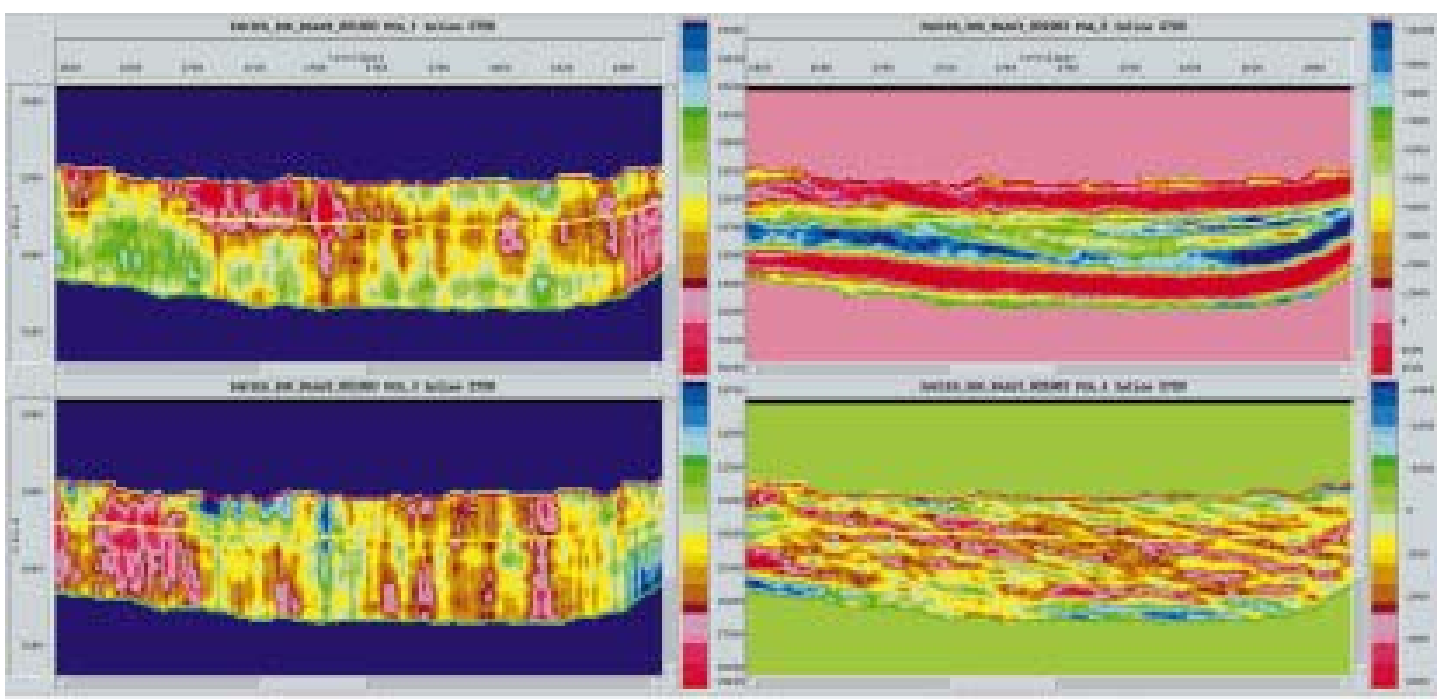

Figura 4 - Inline 2720 do quarto componente principal. A primeira é principalmente definida pela maior contribuição dos volumes de impedância original e menor contribuição da coerência, a segunda pela amplitude. Notar a quarta componente que mostra a tendência do processamento observada nos atributos do volume de empilhamento total e nos traços próximos.

Figure 4 - Inline 2720 from the $4^{\text {th }}$ principal component. The $7^{3 t}$ is mostly defined by a major contribution of impedance original volumes and a minor contribution of coherency, the $2^{\text {nd }}$ by amplitude. Note the $4^{\text {th }}$ component that displays the processing trend observed on the full stack and near attributes.

Based on our available dataset, the tables 1 and 2 display an example of the results of the PCA for an interval of interest defined by the tops of the Eocene and Maastrichtian horizons. Table 1 shows the correlation matrix between each seismic attribute of the input space within the interval and the contribution of each principal component. Table 2 shows the weight of each attribute in the definition of each component principal. The analysis of our input dataset indicates that the 2 first components contributed more than $87 \%$ of the original information. The ultimate components contain a reduced part of each seismic attribute, that could be associated to the noise as observed on the figure (Component principal 4, Figure 4) and. Based on the Eigen values analysis, we have selected those first 2 components, as our input space attributes to the Hierarchical classification, for seismic facies discrimination.

Therefore, the principal component analysis also helped in understanding the relationship between the new attributes defined as PCA and the input attributes. For example, the first PCA component is mostly affected by the 3 impedance-related attributes, with a minor contribution from the coherency attribute. It indicates a strong correlation between the original attributes that contribute to this principal component, as observed in the Table 1 . The $2^{\text {nd }}$ principal component is mainly associated with the variation of the amplitude. However, all input volumes have contributed to the definition of each component.

If we want to relate directly the results of the PCA back to the original attributes, this relation mainly depends on the contribution of each original attributes to the PCA attribute, as seen in the Table 1 and Figure 4. A specific type of attribute could mostly affect the general trend of each principal component.

The Hierarchical Classification (AgipENI patented) is the methodology used for the $3 \mathrm{D}$ multi-attribute seismic volume classification, after the data information reduction stage trough principal component analysis. The classification process consists of 2 steps. First, meaningful subsets of the input data are defined based on the multi-dimensional cross-plot. A representative (cluster node) is assigned to each subset during this step. The subsets are ordered in accordance with their location in the multi-dimensional cross-plot and assigned a class number and a color. Then, individual samples are assigned to the appropriate subsets based on the Euclidean distance.

As the result of the 3D multi-attribute classification, the seismic facies volume is constituted by discrete values associated to each seismic 


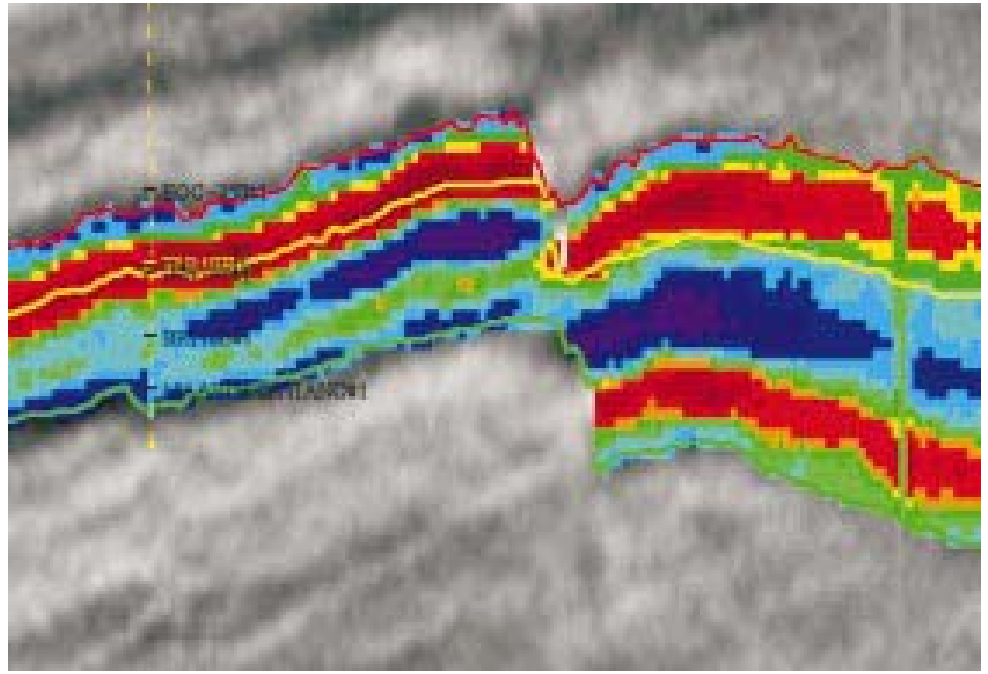

Figura 5 - Detalhe de uma linha aleatória em tempo. Dois volumes de fácies sísmicas definidos pelo topo do Eoceno, Paleoceno e topos do Paleoceno e Maastrichtiano são projetados no volume de amplitudes de empilhamento total. Notar que a distribuiçãa no reservatório inferior da fácies de cor roxa foi correlacionada a distribuição NTG dos reservatórios observados nos poços BR 120 e BR1 10 e a cor marrom indica a distribuição espacial e variação da camada de folhelho de baixa impedância observada na base do reservatório.

Figure 5 - Detail of a time random line. 2 seismic facies volumes, defined by the tops Eocene, Paleocene and tops Paleocene, Maastrichtian are projected on the full stack amplitude attribute. Note the distribution in the lower sand reservoir of the purple facies that has been correlated to the NTG distribution from wells for the BRI20 and BRIIO reservoirs, and the brown that indicates the spatial distribution and variation of the low impedance shale layer observed at the bottom of the reservoir.

sample, which correspond to each cluster defined by the process. The figure 5 presents an example of resulting volume projected on the full stack amplitude attribute, which gathers a separate classification in the interval Top Eocene/Top Paleocene and Top Paleocene/Top Maastrichtian. The color distribution should be investigated per interval. It displays the vertical and lateral variations of the seismic facies. In the lower interval, a specific facies is mostly corresponding to the spatial distribution of the oil sand reservoirs, as we have correlated the results to the NTG maps deduced from the wells.

\section{CONCLUSIONS}

In this paper, we proposed a methodology to be applied at the reservoir characterization stage, as we deal with seismic data that represents the background general trend of our zone of interest. The delivery of a 3D facies volume is a step forward in the understanding of the weight of each original seismic attribute and can be directly interpreted in terms of geological facies. As in any interpretation process, the results of the classification or "the seismic facies volume" after a Principal Component Analysis must be achieved using calibration to well data, or analysis of morphologic patterns on vertical seismic sections, horizon and proportional slices, as well as $3 \mathrm{D}$ views, for analyzing the spatial distribution of a specific facies, regarding other wells data interpretation.

\section{Acknowledgments}

We would like to thank PETROBRAS for permission to publish this work, and our colleagues from PETROBRAS Rio de Janeiro E\&P Asset Team and Research Center (CENPES) for valuable discussions and contributions.

\section{REFERENCES}

POUPON, M.; PALMER, G. Finding channel sands with seismic facies analysis and litho-seismic modeling. Offshore Magazine, [S.I.], v. 59, n. 3, mar. 1999.

JOHANN, P.; RIBET, B. De. Multivariate seismic pattern recognition and Kohonen maps applied on a deep-water turbidite reservoir in Campos Basin, Brazil. In: INTERNATIONAL CONGRESS OF THE BRAZILIAN GEOPHYSICAL SOCIETY, 6., 1999, [S.I.]. Anais...[S.I.: s.n.], 1999. 